Prepared in cooperation with the National Park Service

\title{
Inventory of Data Sources Used for Watershed Condition Assessments of Fire Island National Seashore, Gateway National Recreation Area, and Sagamore Hill National Historic Site, New York and New Jersey
}

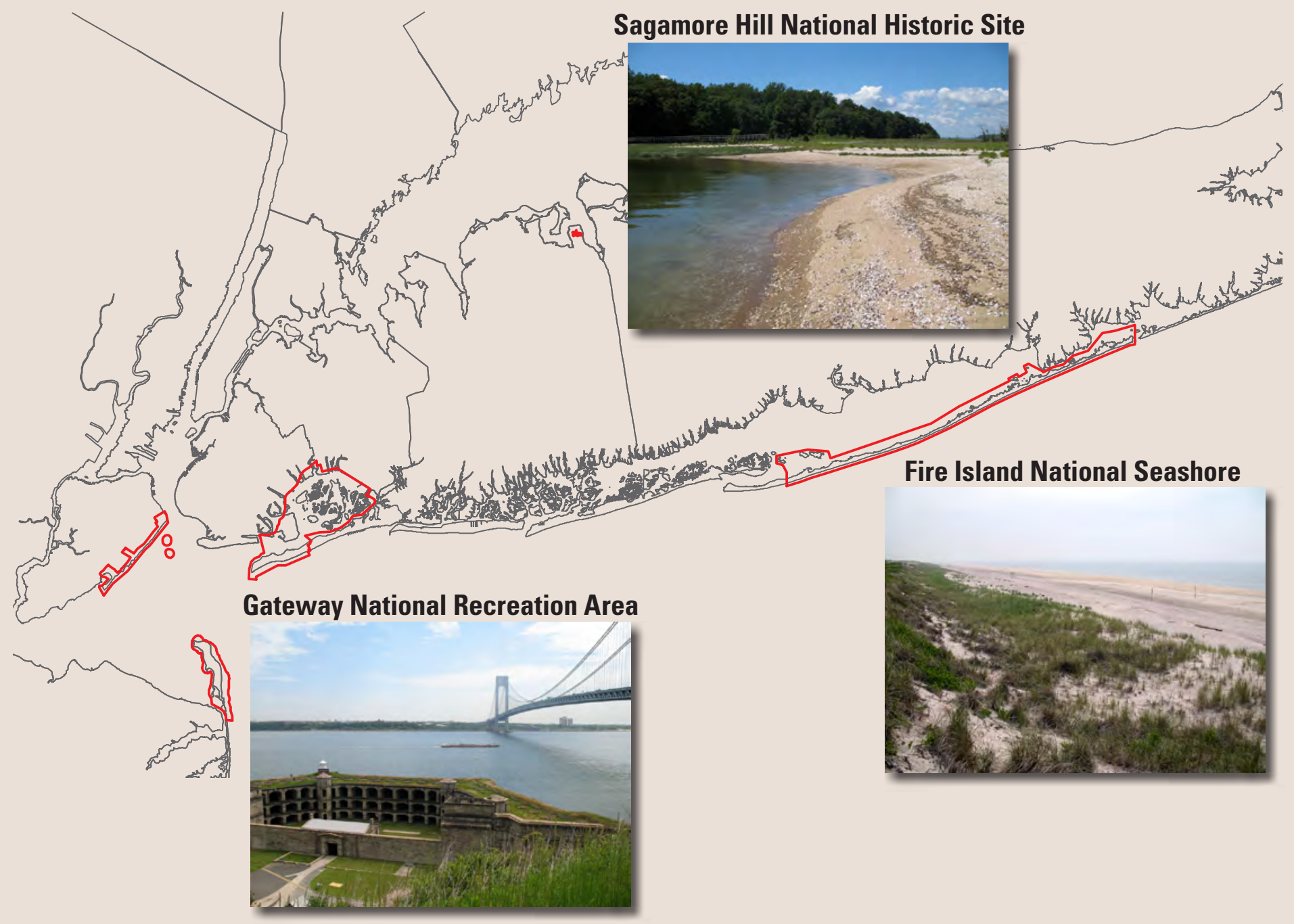

Open-File Report 2008-1298

U.S. Department of the Interior

U.S. Geological Survey 
Cover. Photographs of Fire Island National Seashore, Gateway National Recreation Area, and Sagamore Hill National Historic Site, New York and New Jersey, taken June 2006 by Mark J. Benotti, U.S. Geological Survey. 


\section{Inventory of Data Sources Used for Watershed Condition Assessments of Fire Island National Seashore, Gateway National Recreation Area, and Sagamore Hill National Historic Site, New York and New Jersey}

By Mark J. Benotti

Prepared in cooperation with the National Park Service

Open-File Report 2008-1298 


\title{
U.S. Department of the Interior DIRK KEMPTHORNE, Secretary
}

\author{
U.S. Geological Survey \\ Mark D. Myers, Director
}

U.S. Geological Survey, Reston, Virginia: 2008

For more information on the USGS--the Federal source for science about the Earth, its natural and living resources, natural hazards, and the environment:

World Wide Web: http://www.usgs.gov

Telephone: 1-888-ASK-USGS

Any use of trade, product, or firm names is for descriptive purposes only and does not imply endorsement by the U.S. Government.

Although this report is in the public domain, permission must be secured from the individual copyright owners to reproduce any copyrighted materials contained within this report.

Suggested citation:

Benotti, M.J., 2008, Inventory of data sources used for watershed condition assessments of Fire Island National Seashore, Gateway National Recreation Area, and Sagamore Hill National Historic Site, New York and New Jersey: U.S. Geological Survey Open-File Report 2008-1298, 11 p., online only. 


\section{Contents}

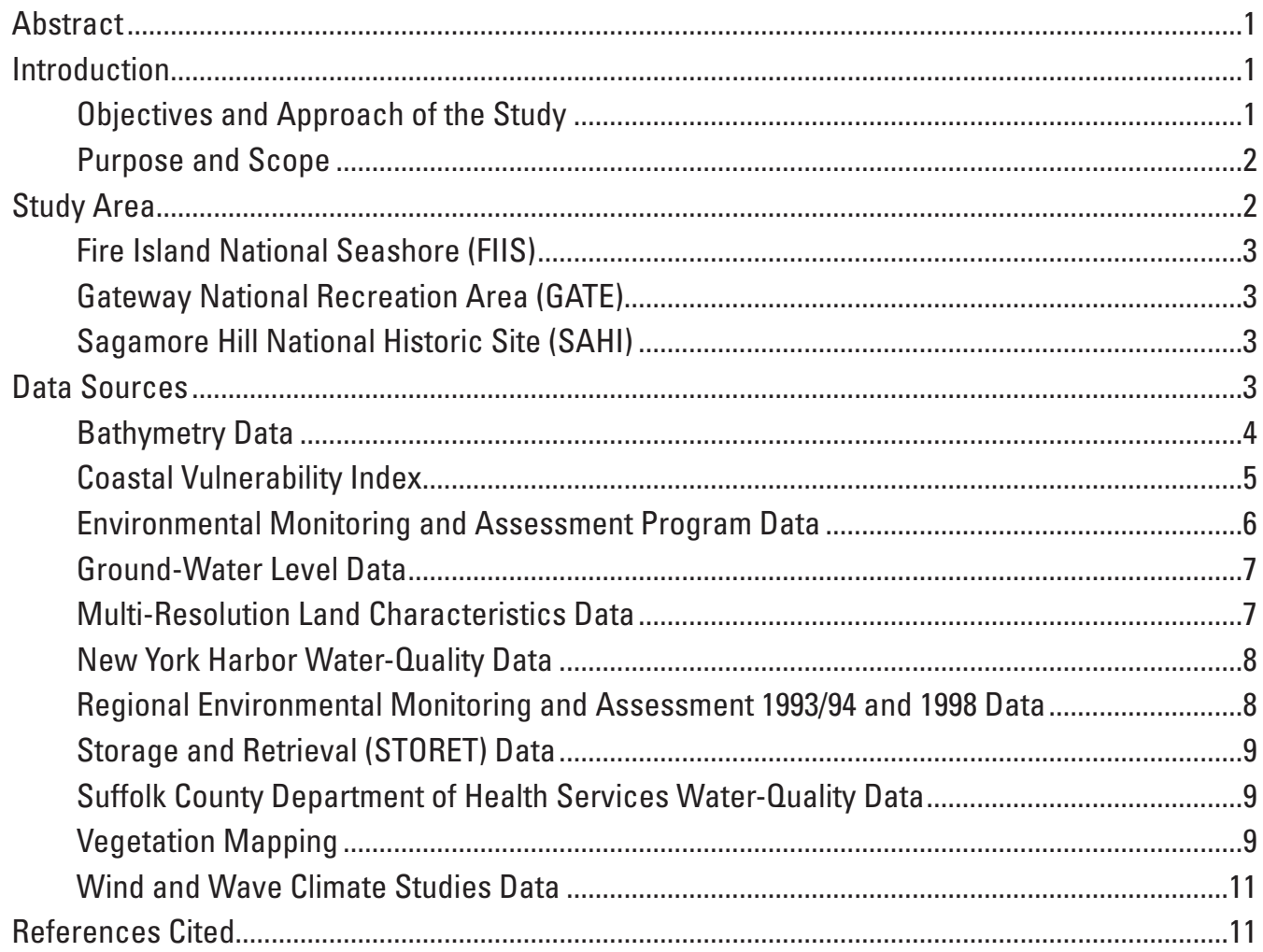

\section{Figures}

1-4. Maps showing-

1. Metropolitan New York and New Jersey locations of Fire Island National Seashore (FIIS), Gateway National Recreation Area (GATE), and Sagamore Hill National Historic Site (SAHI)..

2. Fire Island National Seashore (FIIS) point locations of georeferenced data included in the FIIS Watershed Condition Assessment (WCA)

3. Gateway National Recreation Area (GATE) in New York and New Jersey point locations of georeferenced data included in the GATE Watershed Condition Assessment (WCA)

4. Sagamore Hill National Historic Site (SAHI) in New York point locations of georeferenced data included in the SAHI Watershed Condition Assessment (WCA)

\section{Tables}

1. Georeferenced datasets used in the Watershed Condition Assessment Programs ........6

2. Description of New York Harbor water-quality data for Jamaica Bay, New York............8

3. Description of Storage and Retrieval (STORET) water-quality data for Jamaica Bay and Staten Island, New York, and Sandy Hook, New Jersey...

4. Description of Suffolk County Department of Health Services water-quality data near Fire Island, New York 


\section{Conversion Factors, Datum, and Abbreviations}

\begin{tabular}{lcl}
\hline Multiply & By & To obtain \\
\hline & Length & \\
\hline millimeter $(\mathrm{mm})$ & 0.03937 & inch (in.) \\
centimeter $(\mathrm{cm})$ & 0.3937 & inch (in.) \\
kilometer $(\mathrm{km})$ & 0.6214 & mile (mi) \\
\hline & Area & \\
\hline hectare (ha) & 2.471 & acre \\
square hectometer $\left(\mathrm{hm}^{2}\right)$ & 2.471 & acre \\
square kilometer $\left(\mathrm{km}^{2}\right)$ & 247.1 & acre \\
square kilometer $\left(\mathrm{km}^{2}\right)$ & 0.3861 & square mile $\left(\mathrm{mi}^{2}\right)$ \\
\hline
\end{tabular}

Horizontal coordinate information is referenced to the North American Datum of 1927 (NAD27).

\section{Acronyms}

ANALYTE

Sediment-chemistry compound code (USEPA EMAP)

AVS

Acid volatile sulfides

BASE

Station Classification Code of Base Sampling Site (USEPA EMAP)

CVI

Coastal vulnerability index (USGS-NPS)

DDT

Dichlorodiphenyltrichloroethane, an insecticide

DEM

Digital Elevation Models

EMAP

Environmental Monitoring and Assessment Program (USEPA)

FGDC

Federal Geographic Data Committee

FIIS

Fire Island National Seashore (NPS)

FWS

U.S. Fish and Wildlife Service

GATE

Gateway National Recreation Area (NPS)

GIS

Geographic Information System

GPRA

Government Performance and Results Act

HEP

New York/New Jersey Harbor Estuary Program (USEPA)

L

Large estuary (Variable "strata" from USEPA EMAP)

LISS

Long Island Sound Study

MRLC

Multi-Resolution Land Characteristics

NCA

National Coastal Assessment (USEPA)

NLCD

National Land Cover Database

NOAA

National Oceanic and Atmospheric Administration

NOS

National Ocean Service

NPS

National Park Service 


\begin{tabular}{|c|c|}
\hline NRCS & Natural Resources Conservation Service (USDA) \\
\hline NVCS & National Vegetation Classification System (USGS-NPS, FGDC) \\
\hline NWIS & National Water Information System database (USGS) \\
\hline NYCDEP & New York City Department of Environmental Protection \\
\hline NYNHP & New York Natural Heritage Program (NYSDEC) \\
\hline NYSDEC & New York State Department of Environmental Conservation \\
\hline 0 & Small estuary or tidal river (Variable "strata" from USEPA EMAP) \\
\hline PAH & Polycyclic aromatic hydrocarbons \\
\hline PCB & Polychlorinated biphenyl, a persistent organic compound \\
\hline PEP & Peconic Estuary Program \\
\hline $\mathrm{OA} / \mathrm{OC}$ & Quality assurance/quality control \\
\hline $\mathrm{OC}$ & Queens College \\
\hline REMAP & $\begin{array}{l}\text { Regional Environmental Monitoring and Assessment Program } \\
\text { (USEPA HEP) }\end{array}$ \\
\hline SAHI & Sagamore Hill National Historic Site (NPS) \\
\hline SBU & Stony Brook University \\
\hline SCDHS & Suffolk County Department of Health Services \\
\hline SEM & Simultaneously Extracted Metals \\
\hline STORET & Storage and Retrieval data management system (USEPA) \\
\hline TOC & Total Organic Carbon \\
\hline TR & Tidal river (Variable “strata” from USEPA EMAP) \\
\hline$\mu \mathrm{g} / \mathrm{g}, \mathrm{ng} / \mathrm{g}, \mu \mathrm{moles} / \mathrm{g}$ & $\begin{array}{l}\text { Micrograms per gram, nanograms per gram, and micromoles per gram; } \\
\text { chemical concentrations recorded in dry weight (USEPA EMAP) }\end{array}$ \\
\hline URI & University of Rhode Island \\
\hline USACE & U.S. Army Corps of Engineers \\
\hline USDA & U.S. Department of Agriculture \\
\hline USEPA & U.S. Environmental Protection Agency \\
\hline USGS & U.S. Geological Survey \\
\hline WCA & Watershed Condition Assessment (USGS-NPS) \\
\hline WIS & Water Information Studies (USACE) \\
\hline
\end{tabular}


This page has been left blank intentionally. 


\section{Inventory of Data Sources Used for Watershed Condition Assessments of Fire Island National Seashore, Gateway National Recreation Area, and Sagamore Hill National Historic Site, New York and New Jersey}

\author{
By Mark J. Benotti
}

\section{Abstract}

The natural resources and watershed conditions of National Park units in the New York-New Jersey areaGateway National Recreation Area (GATE), Sagamore Hill National Historic Site (SAHI), and Fire Island National Seashore (FIIS) - are threatened by different degrees of urbanization and direct or indirect human use. Such threats as nutrient enrichment, sedimentation, exotic species invasion, water pollution, and development pose serious management concerns for these parks. Limited investigations of the status of different natural resources at or near each park have been conducted, but a comprehensive understanding of the natural resources and watershed conditions at FIIS, GATE, and SAHI is needed. This report details the sources of spatial data and metadata assembled into a Geographic Information System (GIS) for the purpose of assessing natural resources and watershed conditions at GATE, SAHI, and FIIS.

\section{Introduction}

Congress, in its Fiscal Year 2003 Appropriations Act, instructed and funded the National Park Service (NPS) to assess environmental conditions in watersheds where NPS units are located (accessed August 24, 2007, at http://www. nature.nps.gov/water/watershedconds.cfm). Threats from nutrient enrichment, sedimentation, exotic species, water contamination, and development are management concerns for many coastal NPS parks. Consequently, NPS seeks to improve the understanding and evaluation of the condition of natural resources within coastal park units. This information on natural resources will guide data collection and broader watershed assessment efforts. The Watershed Condition Assessment (WCA) Program of the NPS will identify environmental threats or stressors to the natural resources of the parks and offer options for populating information gaps.
The goals of the WCA are to determine methods to address threats and issues on a watershed or regional oceanographic scale, and guide development of actions to reduce and prevent impairment of waters of our coastal parks through NPS and partnership efforts. Results of this assessment will be integrated into park and service-wide databases and will be used to guide the Department of the Interior land-health goal reporting as prescribed by the Government Performance and Results Act (GPRA) of 1993. To facilitate this ecosystem-level assessment, which relies on georeferenced datasets from a variety of county, state, and Federal agencies, a Geographic Information System (GIS) will be used to organize and interpret appropriate datasets.

The WCA, assembled by researchers at Stony Brook University (SBU), Queens College (QC), and the New York Natural Heritage Program (NYNHP), will address the assessment of natural resources for Fire Island National Seashore (FIIS), Gateway National Recreation Area (GATE), and Sagamore Hill National Historic Site (SAHI; fig. 1). The U.S. Geological Survey (USGS), in cooperation with the NPS, produced this report to provide a comprehensive description of all georeferenced datasets that will be used in subsequent WCA assessments for FIIS, GATE, and SAHI.

\section{Objectives and Approach of the Study}

The principle goals of this study are to:

1. Improve the understanding of the conditions of natural resources within the three NPS units (GATE, SAHI, and FIIS),

2. identify information gaps required for a more complete understanding of watershed and (or) natural resource conditions,

3. determine methods to address threats to natural resources and watershed conditions on a local or regional scale, and

4. provide information that park managers can use to prevent impairment of waters or degradation of natural resources.

The work proceeded in three phases for each WCA as follows: 


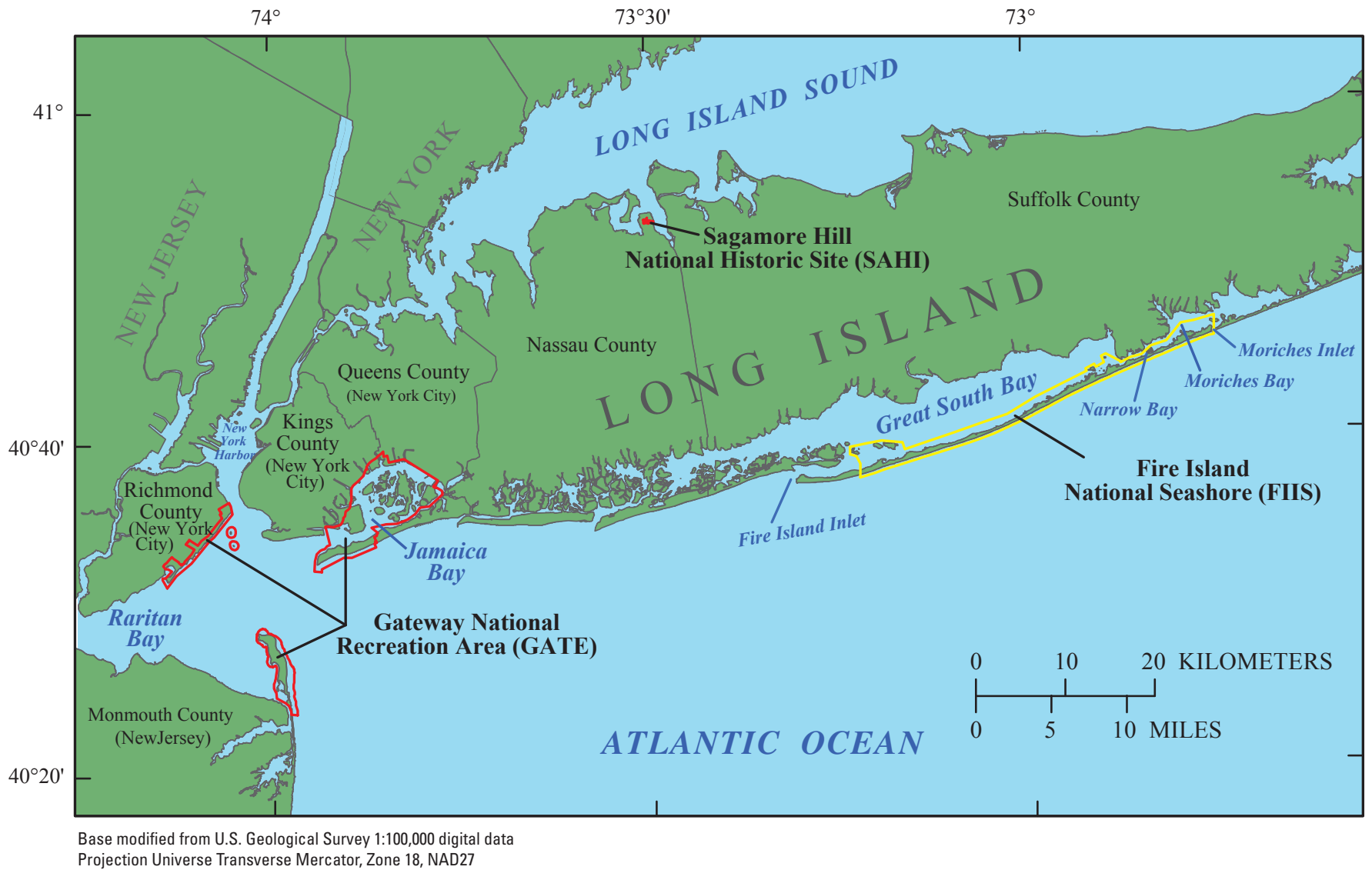

Figure 1. Metropolitan New York and New Jersey showing locations of Fire Island National Seashore (FIIS), Gateway National Recreation Area (GATE), and Sagamore Hill National Historic Site (SAHI).

1. Phase 1 involves identifying the spatial datasets that can be used to assemble the database. Collaborators at SBU and QC participated in this phase; the products from this project will ultimately populate the database. Data in electronic format will be delivered to the University of Rhode Island (URI) for incorporation into the GIS database.

2. Phase 2 involves advising GIS collaborators at URI on how to assemble/manipulate data into a format suitable for each WCA.

3. Phase 3 involves the transfer of the GIS database and associated files compiled at URI to the USGS, SBU, and QC where they will be modified as follows:

a. The USGS will be responsible for a listing of information relating to the incorporated datasets (for example, source, quality, and completeness).

b. $\quad \mathrm{SBU}$ and $\mathrm{QC}$ will be responsible for the final description of the database and dissemination of that information with contributions from the USGS.

\section{Purpose and Scope}

This USGS Open-File Report presents summary information on the electronic data sources to be used in each WCA. Each of the eleven sources of data is described. The data were assembled from various online sources, and when necessary, only those subsets of information relevant to GATE, SAHI, or FIIS were extracted and discussed in this report. This report also provides a brief description of each park, identifying some of the natural resources that will be addressed in the WCA reports.

\section{Study Area}

FIIS, GATE, and SAHI are located in the metropolitan area of New York City and are within $100 \mathrm{~km}$ of the City (fig. 1). FIIS is a $50-\mathrm{km}$ long barrier-island ecosystem along the southern shore of Long Island, N.Y. Dominant ecosystems include nearshore ocean, ocean beach and dunes, maritime forests, freshwater wetlands, and estuarine components such 
as salt marshes, bay beaches, and seagrass meadows. GATE is a fragmented park unit in the New York-New Jersey Harbor Complex. Areas of GATE within New York State include the Jamaica Bay estuary; barrier-island ecosystems associated with Breezy Point, Fort Tilden, and Riis Park; and upland, freshwater wetland and coastal wetland habitats at Floyd Bennett Field and Fort Wadsworth-Staten Island. The New Jersey area of GATE includes Sandy Hook, a barrier peninsula or spit at the mouth of Raritan Bay. SAHI, an 83-acre site on the north shore of Long Island in the town of Oyster Bay, N.Y., contains excellent examples of deciduous forests, salt marsh, and estuarine beach.

All three of these New York-New Jersey area coastal parks are within urban and high-density suburban watersheds, and park managers are continually challenged to address issues such as water-quality degradation, introduction of exotic species, air pollution, habitat fragmentation, and recreational use. These may all have dramatic effects on aquatic ecosystem function, integrity, and habitat quantity and quality.

\section{Fire Island National Seashore (FIIS)}

Fire Island is approximately $50 \mathrm{~km}$ long and $0.5 \mathrm{~km}$ wide and is bounded by the Great South Bay, Narrow Bay, and Moriches Bay estuaries to the north; the Atlantic Ocean to the south; and Fire Island Inlet and Moriches Inlet to the west and east (fig. 2). The 79- $\mathrm{km}^{2}$ Fire Island study area encompasses the entire barrier island and includes most of the adjacent marine surface waters within the boundaries of FIIS.

\section{Gateway National Recreation Area (GATE)}

GATE is a fragmented $105 \mathrm{~km}^{2}$ area in the New York City metropolitan area (fig. 3). In New York State, GATE includes the Jamaica Bay and Breezy Point Units, both in southern Queens County, and the Staten Island Unit in southeastern Richmond County. In New Jersey, it includes the Sandy Hook Unit in eastern Monmouth County. GATE has diverse ecosystems including near-shore ocean, ocean beach and dunes, maritime forests, freshwater wetlands, and estuarine components such as salt marshes, bay beaches, and seagrass meadows. Additionally, the park's natural resources are some of the most threatened because of its proximity to highly urbanized areas of New York City.

\section{Sagamore Hill National Historic Site (SAHI)}

Sagamore Hill National Historic Site was the home of President Theodore Roosevelt from 1886 until his death in 1919. It was created to preserve the house and associated cultural resources (fig. 4). Natural resources associated with the 83-acre property include upland deciduous forest, relic agricultural land, salt marshes, and bay-side beach areas.

\section{Data Sources}

The following sections provide an inventory of data sources for all three parks. Where available, descriptive metadata are provided, as well as a citation for accessing the

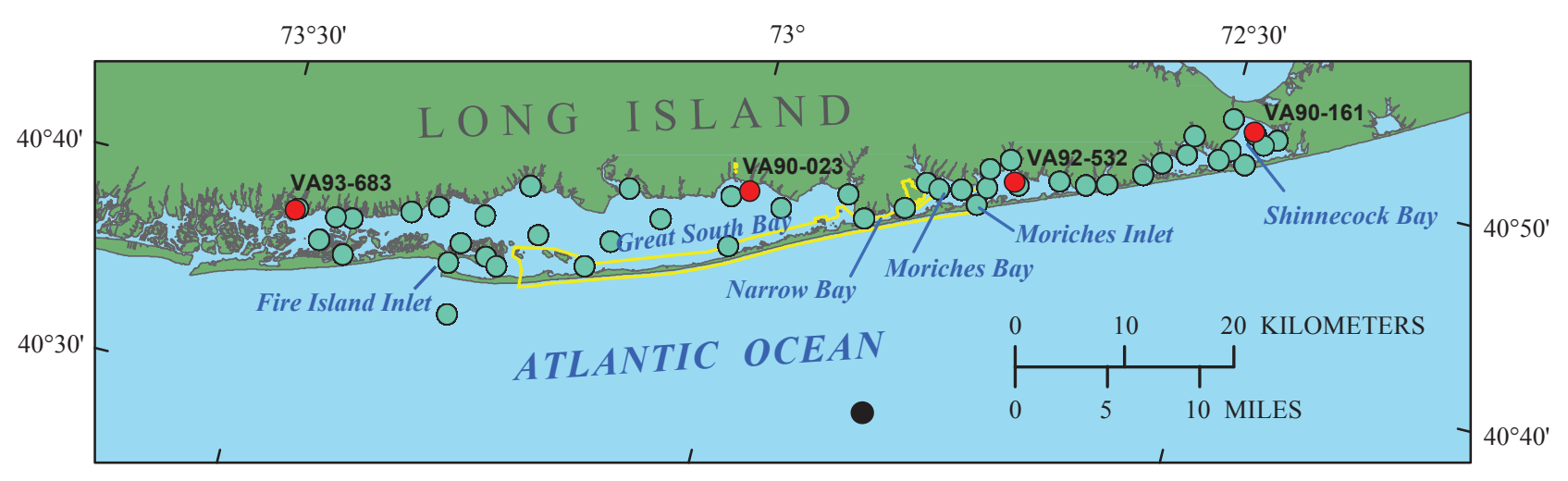

Base modified from U.S. Geological Survey 1:100,000 digital data

Projection Universe Transverse Mercator, Zone 18, NAD27

\section{EXPLANATION}

Emergency Monitoring and Assessment Program (EMAP) stations with station names

Suffolk County Department of Health Services (SCDHS) stations

U.S. Army Corps of Engineers (USACE) site 114

Fire Island National Seashore (FIIS) boundary

Figure 2. Fire Island National Seashore (FIIS) showing point locations of georeferenced data included in the FIIS Watershed Condition Assessment (WCA). Data with more extensive coverages, such as bathymetry, are not depicted. 


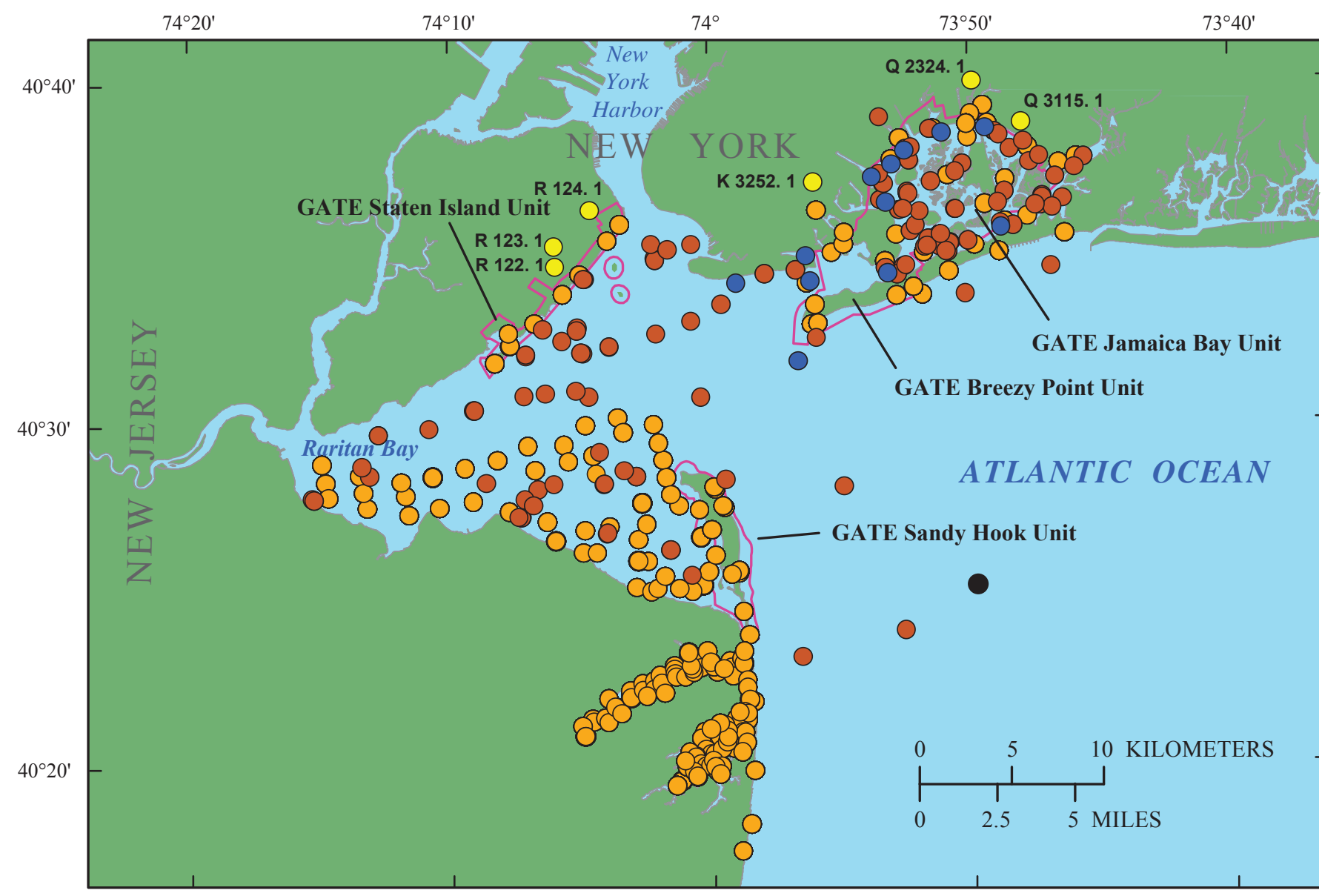

Base modified from U.S. Geological Survey 1:100,000 digital data Projection Universe Transverse Mercator, Zone 18, NAD27

\section{EXPLANATION}

U.S. Geological Survey (USGS) gound-water wells with site names

- New York City Department of Environmental Protection (NYCDEP) stations

- Regional Emergency Monitoring and Assessment Program (REMAP) stations

Storage and Retrieval (STORET) stations

- U.S. Army Corps of Engineers (USACE) site 126

$\square$ Gateway National Recreation Area (GATE) boundary

Figure 3. Gateway National Recreation Area (GATE) in New York and New Jersey showing point locations of georeferenced data included in the GATE Watershed Condition Assessment (WCA). Data with more extensive coverages, such as bathymetry, are not depicted.

original data. A list of the data highlighting which datasets are used in the associated WCA projects is provided in table 1.

\section{Bathymetry Data}

The National Oceanic and Atmospheric Administration (NOAA) maintains a database of bathymetric data for all United States marine inshore, coastal, and exclusive economic zone waters (National Ocean Service, 1998a and 1998b). Data are housed at the National Ocean Service (NOS) Hydrographic Data Base and consist of digitized data from smooth sheets of hydrographic surveys completed during 1851 to 1965 as well as survey data acquired digitally on NOS survey vessels since 1965 .

Bathymetric Digital Elevation Models (DEM) were generated from original point soundings collected during hydrographic surveys conducted by the NOS and its predecessors. Mean High Water shoreline as defined by NOAA nautical charts was used as a constraining boundary and assigned its local elevation relative to the local datum (typically Mean Low Water). DEM grid values outside the shoreline (on land) were assigned null values (-32676). In the event of multiple surveys in a region, the most recent survey 


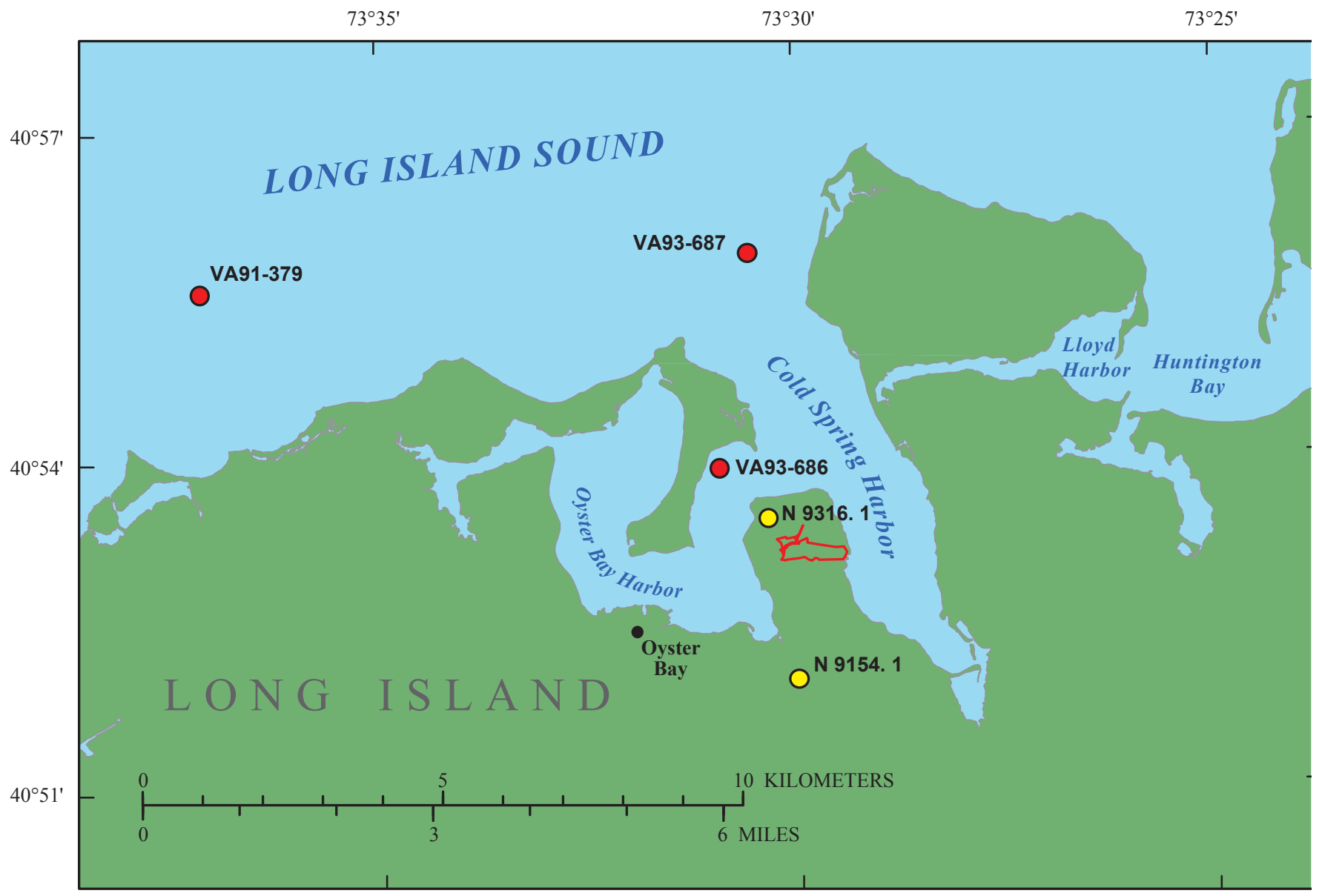

Base modified from U.S. Geological Survey 1:100,000 digital data Projection Universe Transverse Mercator, Zone 18, NAD27

\section{EXPLANATION}

Emergency Monitoring and Assessment Program (EMAP) stations with station names U.S. Geological Survey (USGS) ground-water wells with site names Sagamore Hill National Historic Site (SAHI) boundary

Figure 4. Sagamore Hill National Historic Site (SAHI) in New York showing point locations of georeferenced data included in the SAHI Watershed Condition Assessment (WCA). Data with more extensive coverages, such as bathymetry, are not depicted.

soundings were retained. Both 7.5-minute and 1-degree DEMs are available. Coverages are available for many, but not all, of the estuaries of the contiguous United States. Data for waters adjacent to FIIS, GATE, and SAHI were downloaded from the NOAA National Geophysical Data Center home page (accessed February 21, 2007, at http://estuarinebathymetry. noaa.gov) and incorporated into a GIS.

\section{Coastal Vulnerability Index}

The USGS, in partnership with the NPS Geologic Resources Division, conducted hazard assessments in 2001 of future sea-level change by creating maps to aid in the management of NPS' valuable resources. The result was the synthesis of a coastal vulnerability index (CVI) assessment for several national park units, highlighting areas that are likely to be most affected by future sea-level rise. Through the use of a CVI, the likelihood that physical changes will occur as sea-level rises is quantified on the basis of the following criteria: tidal range, wave height, coastal slope, shoreline change, geomorphology, and historical rate of relative sea-level rise. This approach combines a coastal system's susceptibility to change with its natural ability to adapt to changing environmental conditions and yields a relative measure of the system's natural vulnerability to the effects of sea-level rise. NPS staff use the CVI data for long-term resource management planning; park facilities planning, such as relocating building or roads; and assessing long-term threats to resources. 
Table 1. Georeferenced datasets used in the Watershed Condition Assessment Programs.

[NOAA, National Oceanic and Atmospheric Administration; NOS, National Ocean Service; USGS, U.S. Geological Survey; NPS, National Park Service; NWIS, National Water Information System; NYCDEP, New York City Department of Environmental Protection; USEPA, U.S. Environmental Protection Agency; NYNHP, New York National Heritage Program; USACE, U.S. Army Corps of Engineers; WIS, Water Information Studies]

\begin{tabular}{lccc}
\hline \multicolumn{1}{c}{ Dataset } & $\begin{array}{c}\text { Fire Island } \\
\text { National Seashore }\end{array}$ & $\begin{array}{c}\text { Gateway National } \\
\text { Recreation Area }\end{array}$ & $\begin{array}{c}\text { Sagamore Hill } \\
\text { National Historic } \\
\text { Site }\end{array}$ \\
\hline Bathymetry Data (NOAA, NOS) & $\mathrm{X}$ & $\mathrm{X}$ & $\mathrm{X}$ \\
Coastal Vulnerability Index (USGS-NPS CVI) & $\mathrm{X}$ & $\mathrm{X}$ & $\mathrm{X}$ \\
Environmental Monitoring and Assessment Program Data (USEPA EMAP) & $\mathrm{X}$ & $\mathrm{X}$ & $\mathrm{X}$ \\
Ground-Water Level Data (USGS NWIS) & $\mathrm{X}$ & $\mathrm{X}$ & $\mathrm{X}$ \\
Multi-Resolution Land Characteristics Data (MRLC) & & $\mathrm{X}$ & $\mathrm{X}$ \\
New York Harbor Water Quality Data (NYCDEP) & & \\
Regional Environmental Monitoring and Assessment 1993/94 and 1998 Data & & $\mathrm{X}$ \\
$\quad$ USEPA REMAP) & & $\mathrm{X}$ & $\mathrm{X}$ \\
Storage and Retrieval Data (USEPA STORET) & $\mathrm{X}$ & $\mathrm{X}$ & \\
Suffolk County Department of Health Services (SCDHS) & & & \\
Vegetation Mapping (USGS-NPS, NYNHP) & & & \\
Wind and Wave Climate Studies Data (USACE WIS) & & & \\
\hline
\end{tabular}

The CVI assessments for FIIS (Pendleton and others, 2004 and 2005) and GATE were downloaded from the USGS Woods Hole Science Center website (accessed March 14, 2007, at http://woodshole.er.usgs.gov/project-pages/nps-cvi/ parks/FIIS.htm and GATE.htm) and incorporated into a GIS.

\section{Environmental Monitoring and Assessment Program Data}

The U.S. Environmental Protection Agency (USEPA) Environmental Monitoring and Assessment Program (EMAP) is a research program to develop the tools necessary to monitor and assess the status and trends of national ecological resources. The goal of EMAP is to develop the scientific understanding for translating environmental monitoring data from multiple spatial and temporal scales into assessments of current ecological condition and forecasts of future risks to our natural resources. During 1990-93, 425 stations were sampled throughout the Virginian Province (the coastal and estuarine area extending from the Virginia-North Carolina Border north to Cape Cod, Massachusetts).

EMAP data include station location and information data, sediment data (sediment-chemistry, grain composition, and toxicity-test data), water-quality data, benthic data (benthic species abundance and benthic community data), and fish data (fish species abundance and fish community data). Because of the relative proximity of station locations to the park properties, four EMAP stations (VA93-683,
VA90-023, VA92-532, and VA90-161; fig. 2) were of interest to the FIIS WCA, and three stations (VA91-379, VA93-686, and VA93-687; fig. 4) were of interest to the SAHI WCA. All these datasets were downloaded from the EMAP online database (accessed March 2, 2007, at http://www.epa.gov/ emap/) and included in a GIS.

The EMAP-estuaries stations dataset contains geographic and statistical information on stations in the Virginian Province that have a Station Classification Code of Base Sampling Site (BASE). If a BASE station also met the criteria for another station classification, then other monitoring activities were included in the suite of samples expected for the station. These stations were located randomly, based on a are included. Some variables present descriptive geographic information. The two (2) character mailing code for the State inside whose geopolitical boundaries the station lies is recorded. The system code indicates the large body of water or watershed in which the station site is located. Estuary defines the specific river, bay, creek, or other small water body in which the station is located.

Other variables are included for statistical purposes. Strata indicates a broad water-body category assigned to a station. These include Large Estuary (L), Small Estuary or Tidal River (O) or large Tidal River (TR). These categories serve to aggregate and (or) segregate the data for statistical purposes. A station area is calculated for each station for weighting the data collected at a station on a parameter basis. The value is the actual area represented by a station. 
The sediment-chemistry dataset contains a suite of chemical concentrations derived from analyses of surfacesediment samples collected from all stations in the Virginian Province. Individual and summed analyte concentrations are included. A code for each compound is given under ANALYTE. These include 18 inorganic, 57 organic, 5 organic concentration sums and Total Organic Carbon (TOC). Concentrations are recorded in dry weight. Units are reported under a separate attribute: $\mu \mathrm{g} / \mathrm{g}, \mathrm{ng} / \mathrm{g}$, percent or $\mu$ moles $/ \mathrm{g}$. Quality Assurance (QA)/Quality Control (QC) issues are coded. Depending on the QA code, only a detection limit may be recorded.

The sediment grain-size dataset contains the results of grain-composition analyses. These analyses were conducted on a surface-sediment sample collected at a station. Sediment grain-size analyses were conducted on a sample extracted from a sediment homogenate. The sample was derived from sediment that was scraped from the top $2 \mathrm{~cm}$ of several grab samples and homogenized. The homogenate was divided into samples for sediment-chemistry analysis, a sediment toxicity test, and full sediment grain-size analysis. The grain-size analyses included measurements of sand, silt, clay, percent of sand, percent of silt/clay, quartile, quartile deviation, and skewness.

The sediment-toxicity test dataset provides summary data on a sediment-toxicity test associated with a station. The test was conducted using an homogenized sample composed of several grab samples. A static 10-day sediment-toxicity test was conducted using the amphipod Ampelisca abdita. The mean test sample survival as percent of the mean control survival is recorded. A flag indicates whether test and control mortalities were significantly different.

The vertical profile water-quality file provides a snapshot of the acceptable vertical profiles made at a station. The reported surface measurements were made within one (1) meter of the surface, whereas bottom measurements were made within one (1) meter of the bottom. Values were calculated for several characteristics, including surface and bottom density, maximum fluorescence, rate of light extinction, and compensation depth. If a file specification is cited, QA/QC code(s) are recorded. Suspended-solids concentration was measured in a surface water sample.

The benthic-species dataset presents summary data on each benthic taxon identified across all acceptable grabs collected at a station. A count of organisms of the taxon identified from all grabs (generally 3 ) is recorded. The mean abundance and standard deviation of the mean abundance are also recorded. Each taxon is identified by a unique code which can be cross-referenced to the taxon phylogeny. Physical constraints or QA problems precluded the collection or analysis of all samples at a few stations.

The benthos dataset summarizes at the community level the data collected from the benthic grabs taken at each station. Three benthic samples for taxon identification generally were collected at each station. A total and mean count of taxa and individuals were calculated for all taxa and infaunal and epifaunal taxa. The total and mean biomass and mean moisture and silt/clay content are recorded for each station. Field data were averaged to generate the mean grab penetration depth; however, values for mean depth to the Redox Potential Discontinuity layer are not included.

Physical constraints or QA problems precluded the collection or analysis of all the sample types at a few stations. The total number of grab samples collected at a station that passed QA/QC procedures for collection, shipment, and analysis is recorded.

The Fish Species dataset is a synopsis of one successful standard trawl conducted at a station. The total count of individuals of each fish taxon caught in the standard trawl is reported. The length $(\mathrm{mm})$ of as many as 30 individuals caught in a standard trawl was measured, according to protocol. If there were two or more individuals of a taxon, the mean length and standard deviation of the mean were calculated and recorded. The length is recorded for an individual. A count of pathologies observed on all individuals of a taxon may be summarized for up to four categories: body, ocular, branchial, and buccal. Each taxon is identified by a unique code which can be cross-referenced to the taxon phylogeny.

The Fish Community data-set is a synopsis of one successful standard trawl conducted at a station. The total number of fish species and individuals of all species caught in the standard trawl is recorded. Material of anthropogenic or natural origins may have been collected $(\mathrm{Y} / \mathrm{N})$ in the trawl. Manmade trash includes plastics, cans, tires, glass, paper, wood, medical waste, metal objects, balls, or fishing gear. Natural material includes dead fish and natural wood. The gross external body, branchial, buccal, and ocular pathology data are recorded for 1990.

\section{Ground-Water Level Data}

Ground-water level data were downloaded from the USGS National Water Information System (NWIS) database (U.S. Geological Survey, 2007), accessed at http:// waterdata.usgs.gov/nwis/si. This database consists of more than 850,000 records of wells, springs, test holes, tunnels, drains, and excavations in the United States. Available site descriptive information includes well-location and completion information, such as latitude, longitude, well depth, and aquifer. NWIS water-level data were queried and used to construct hydrographs for wells representative of the shallow ground-water system relevant to GATE (Site Name "K 3252. 1", "Q 2324. 1", "Q 3115. 1", "R 122. 1", "R 123. 1", and "R 124. 1"; fig. 3) and SAHI (Site Name "N 9154. 1" and "N 9316. 1"; fig. 4).

\section{Multi-Resolution Land Characteristics Data}

The National Land Cover Database (NLCD) was produced through a cooperative project conducted by the Multi-Resolution Land Characteristics (MRLC) Consortium. 
The MRLC Consortium is a partnership of Federal agencies, consisting of the USGS, NOAA, USEPA, U.S. Department of Agriculture (USDA), U.S. Forest Service, NPS, U.S. Fish and Wildlife Service (FWS), Bureau of Land Management, and USDA Natural Resources Conservation Service (NRCS). One of the primary goals of the project is to generate a current, consistent, seamless, and accurate National Land Cover Database circa 2001 for the United States at medium spatial resolution. The NLCD 2001 (U.S. Geological Survey, 2003) was created by partitioning the United States into mapping zones. A total of 66 mapping zones were delineated within the conterminous United States on the basis of ecoregion and geographical characteristics, edge matching features, and the size requirement of Landsat mosaics. Data for New York (zone 65 in the MRLC mapping scheme) covering all areas of FIIS, GATE, and SAHI were downloaded from the MRLC online database and included in a GIS.

\section{New York Harbor Water-Quality Data}

The New York City Department of Environmental Protection (NYCDEP) monitors water quality throughout New York Harbor. They maintain georeferenced water-quality data, which have been collected at different locations, since 1909. At present, 51 stations are routinely monitored for a variety of water-quality characteristics, including nitrogen and phosphorous nutrients, dissolved oxygen, Secchi depth, and fecal coliform and total coliform bacteria. These data are used by regulators, scientists, educators and citizens to assess the effects of urbanization, as well as trends and improvements in the water-quality of New York Harbor. Water quality throughout the harbor has improved since initial water-quality surveys in the early 20th century, and the annual New York Harbor Water Quality Report summarizes current trends in water quality (New York City Department of Environmental Protection, 2004).

Water-quality data are not available online, and were obtained directly from the NYCDEP (Beau Ranheim, New York City Department of Environmental Protection, written commun., 2006). Those NYCDEP sites relevant to this report include those in and around Jamaica Bay. The characteristics of interest to this report include nitrite plus nitrate and ammonia. Details of these data are presented in table 2.

\section{Regional Environmental Monitoring and Assessment 1993/94 and 1998 Data}

The USEPA and the New York/New Jersey Harbor Estuary Program (HEP) developed a sediment management and monitoring strategy using data collected in the summers of 1993 and 1994, and again in 1998 (Adams and Hunt, 1993; Adams and others, 1996; Overton and others, 1993; Reifsteck and others, 1993; U.S. Environmental Protection Agency, 1993; Adams, 1998). In all, 168 sites in New York Harbor and New York Bight were sampled in 1993 and 1994, and 112 in 1998, as part of the Regional Environmental Monitoring and Assessment Program (REMAP). The REMAP data for each of these sites includes station location and visit data, sediment information (sediment analyte concentrations, microtox assay test results, amphipod sediment toxicity test results, and sediment composition), water-quality data (for both surface and bottom water), and benthic information (benthic species replicate abundance and benthic replicate biomass). All these datasets were downloaded from the REMAP online database (accessed May 16, 2007, at http://www.epa.gov/emap/remap) and included in a GIS.

The station location and visit datasets provide geographic and visit information for the sites sampled in the New York/ New Jersey Harbor region. The latitude and longitude for each station are recorded, as well as the area represented by a station. The water column depth at the time of sampling and the presence/absence of trash also are recorded. Stations were selected probabilistically using a stratified random design.

The sediment analyte concentrations dataset contains the concentrations of a suite of analytes measured in surficial sediment samples. These samples were collected in the New York/New Jersey Harbor region. The suite of compounds analyzed include: 4 major and 12 trace inorganic elements, 23 polycyclic aromatic hydrocarbons (PAHs), DDT and its metabolites, 10 other chlorinated pesticides, 20 PCB congeners, 17 dioxin and furan congeners (only analyzed in samples from selected regions), total organic carbon (TOC), mono-, di-, tri- and tetra-butyltins, and acid volatile sulfides (AVS)/Simultaneously Extracted Metals (SEM).

The microtox assay test dataset contains results of a toxicity test conducted using the luminescent bacterium, Photobacterium phosphoreum. The supernatant from sediment samples collected in the New York/New Jersey Harbor region was tested and results were compared to results from control samples.

The amphipod sediment toxicity test dataset contains the mean results of sediment toxicity tests conducted using

Table 2. Description of New York Harbor water-quality data for Jamaica Bay, New York.

\begin{tabular}{lccc}
\hline \multicolumn{1}{c}{ Constituent } & Years of data coverage & Number of observations & Collecting agency \\
\hline Ammonia & $1974-2004$ & 3,576 & New York City Department of Environmental Protection \\
Nitrite plus nitrate & $1974-2004$ & 3,594 & New York City Department of Environmental Protection \\
\hline
\end{tabular}


the tube-dwelling amphipod, Ampelisca abdita. The samples were collected in the New York/New Jersey Harbor region. Five replicate 10-day, static, non-renewal toxicity tests were compared to results of a control test.

The sediment composition dataset contains percent of silt/clay measured in a sample. These samples were calculated in the New York/New Jersey Harbor region. The samples were collected from a homogenate from several grab samples.

The vertical profile surface and bottom dataset contains summary data from a vertical profile made at a site. Surface and bottom data for temperature, $\mathrm{pH}$, salinity, and dissolved oxygen are recorded, as well as the bottom depth. Ambient measurements of dissolved oxygen, temperature, and salinity also were collected at the surface.

The benthic species replicate abundance dataset contains information on each benthic taxon identified in each acceptable grab sample collected at a station. A count of organisms of the taxon identified from each grab sample is recorded. Each taxon is identified by Latin name.

The benthic replicate biomass dataset contains information on the biomass of groups of benthic organisms identified in each acceptable grab sample collected at a station. Biomass is recorded in grams. Each group is identified by Latin name.

\section{Storage and Retrieval (STORET) Data}

The STORET data management system (STOrage and RETrieval) is an USEPA database containing environmental data relating to water quality. The database contains raw biological, chemical, and physical data on surface and ground water collected by Federal, state and local agencies, Indian Tribes, volunteer groups, academics, and others. All 50 States, territories, and jurisdictions of the United States are represented in the system. Each record in STORET is accompanied by the location of the sample (latitude, longitude, state, county, Hydrologic Unit Code (HUC), and a brief site identification), time the sample was collected, medium sampled (for example, water, sediment, fish tissue), and name of the organization that sponsored the collection. In addition, STORET contains information on why the data were gathered, sampling and analytical methods used, laboratory used to analyze the samples, quality-control checks used, and personnel responsible for the data. Each provider is responsible for the data it submits to STORET.

Data for GATE were downloaded from STORET (accessed September 25, 2006, at http://www.epa.gov/storet/). The parameters of interest to the GATE WCA are nutrient concentrations (nitrate, nitrite plus nitrate, and ammonia), dissolved oxygen, salinity, fecal coliform and total coliform bacteria. Additionally, because GATE occupies three different areas (in Jamaica Bay and Staten Island in New York; and Sandy Hook in New Jersey), STORET data were separated spatially for each of the aforementioned characteristics. Details of these data are presented in table 3 .

\section{Suffolk County Department of Health Services Water-Quality Data}

The Suffolk County Department of Health Services (SCDHS) Office of Ecology routinely monitors marine surface waters throughout the county as part of various environmental and management programs, including the Peconic Estuary Program (PEP), the Long Island Sound Study (LISS), the South Shore Estuary Reserve, various Harmful Algal Bloom studies (Brown Tide, Pfiesteria, and Paralytic Shellfish Poisoning), and the U.S. Environmental Protection Agency National Coastal Assessment (NCA) program. The SCDHS Office of Ecology also conducts various environmental investigations and water-quality surveys in response to citizen's complaints and (or) requests from elected officials and routinely provides assistance to other agencies, consulting groups, and academia, by conducting water-quality related projects. The SCDHS Office of Ecology also monitors the water quality at all public bathing beaches to ensure that bacterial levels do not exceed State criteria.

SCDHS maintains a database of water-quality measurements made throughout Great South Bay, Moriches Bay, and Shinnecock Bay. All data collected from 1976 through 2004 (the most recent year for which data have been approved and published) were obtained from the SCDHS (Robert Nuzzi, Suffolk County Department of Health Services, written commun., 2006) and entered into a GIS (fig. 2). Characteristic of interest for this study are ammonia, dissolved oxygen, nitrate, nitrite, salinity, temperature, fecal coliform and total coliform bacteria, and total phosphate. Data on each characteristic span the entire period of record and are summarized in table 4.

\section{Vegetation Mapping}

The NPS Vegetation Mapping Projects at Fire Island National Seashore and Gateway National Recreation Area produced a dataset to depict the association-level vegetation for the entire length of Fire Island and the William Floyd Estate, as well as the three park units of GATE (New York Natural Heritage Program, 2002; New York Natural Heritage Program, 2007). Vegetation datasets for FIIS were interpreted, delineated, and digitized from 1:1200-scale true-color aerial photographs taken in April 1997. Vegetation datasets for GATE were created from 2002 color infrared stereo pairs at 1:8,000 scale and were digitally ortho rectified into photo mosaics. The coverages are attributed to the National Vegetation Classification System (NVCS) associations and include height, pattern, and density information. The purpose of these data is to provide the managers and researchers at FIIS and GATE with an accurate spatially referenced dataset to assist in their efforts. 
Table 3. Description of Storage and Retrieval (STORET) water-quality data for Jamaica Bay and Staten Island, New York, and Sandy Hook, New Jersey.

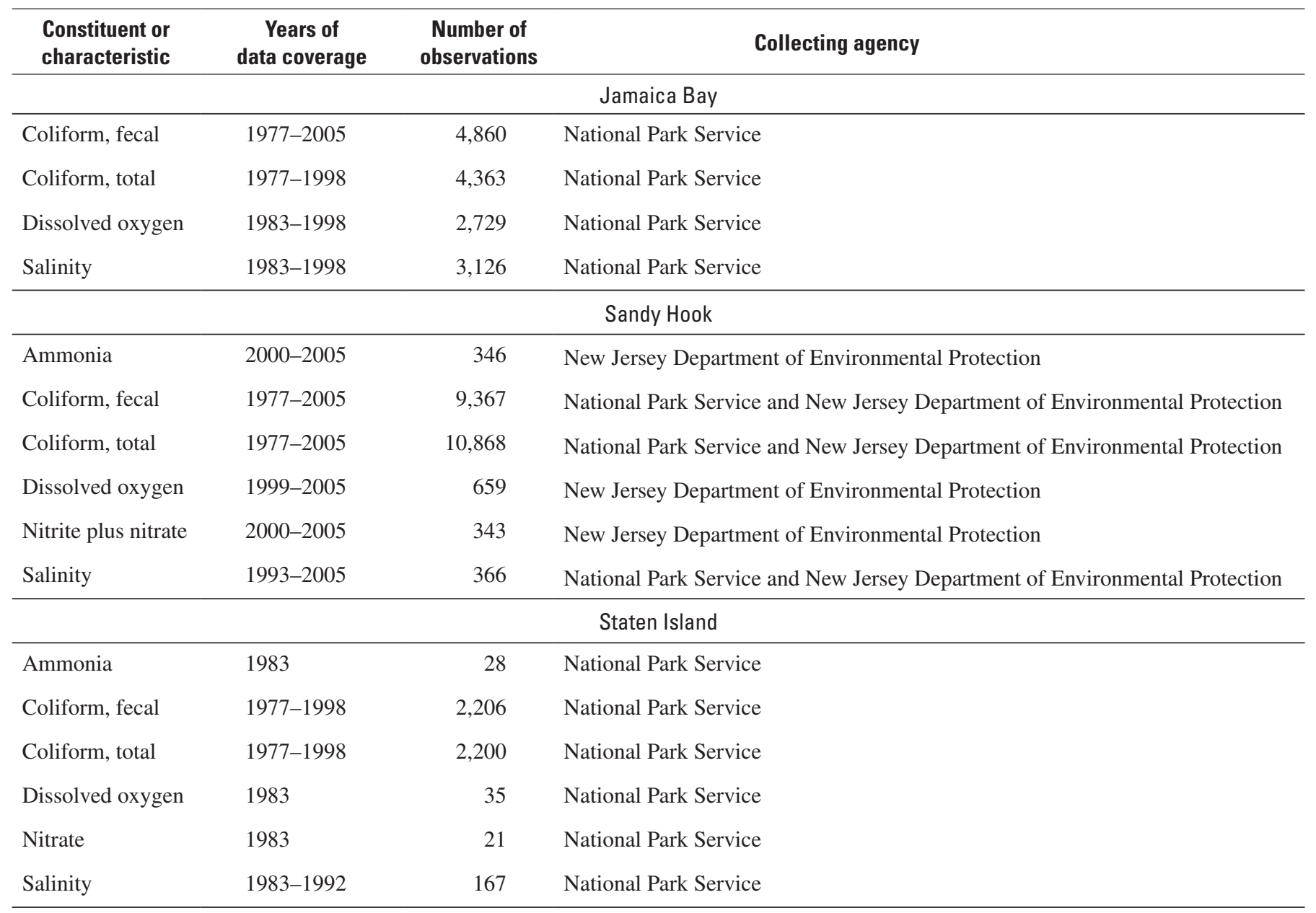

Table 4. Description of Suffolk County Department of Health Services (SCDHS) water-quality data near Fire Island, New York.

\begin{tabular}{lcc}
\hline \multicolumn{1}{c}{$\begin{array}{c}\text { Constituent or } \\
\text { characteristic }\end{array}$} & $\begin{array}{c}\text { Years of } \\
\text { data coverage }\end{array}$ & $\begin{array}{c}\text { Number of } \\
\text { observations }\end{array}$ \\
\hline Ammonia & $1976-2004$ & 5,607 \\
Coliform, fecal & $1976-2004$ & 6,842 \\
Coliform, total & $1976-2004$ & 6,842 \\
Dissolved oxygen & $1976-2004$ & 9,949 \\
Nitrate & $1976-1987$ & 1,479 \\
Nitrite & $1976-1986$ & 2,090 \\
Nitrite plus nitrate & $1988-2004$ & 4,004 \\
Phosphate, total & $1976-1990$ & 5,948 \\
Salinity & $1976-2004$ & 8,243 \\
Temperature & $1976-2004$ & 11,707 \\
\hline
\end{tabular}




\section{Wind and Wave Climate Studies Data}

The United States Army Corps of Engineers (USACE) was authorized in 1976 to produce a series of wave and wind climate studies for United States Coastal Waters (U.S. Army Corps of Engineers, 2004). Wave Information Studies (WIS) data are generated by numerical simulation of past wind and wave conditions, a process called hindcasting. Knowledge of the wave climate is required to design and maintain the Nation's coastal navigation and shore protection projects. Using the USACE online database (accessed May 16, 2007, at http://www.frf.usace.army.mil/cgi-bin/wis/atl/atl_main. $\mathrm{html}$ ), wind and wave roses were produced at site $\overline{114}\left(40.58^{\circ}\right.$, $-73.83^{\circ}$; fig. 2) to estimate average wind and wave conditions for FIIS and at site $126\left(40.42^{\circ},-73.83^{\circ}\right.$; fig. 3) to estimate average wind and wave conditions for GATE over the entire temporal span of the database, from 1980 to 1999.

\section{References Cited}

Adams, D.A., 1998, Quality Assurance Project Plan for Environmental Monitoring, A 5-year Revisit of Sediment Quality in the NY/NJ Harbor: Edison, N.J., U.S. Environmental Protection Agency-Region 2.

Adams, D.A., and Hunt, M., 1993, Quality Assurance Project Plan for Environmental Monitoring Projects, Sediment Quality of the NY/NJ Harbor: Edison, N.J., U.S. Environmental Protection Agency-Region 2.

Adams, D.A., O'Connor, J.S., and Weisberg, S.B., 1996, Sediment Quality of the NY/NJ Harbor System, Draft Final Report, October, 1996: Edison, N.J., U.S. Environmental Protection Agency-Region 2.

National Ocean Service, 1998a, Estuarine bathymetric digital elevation models ( 30 meter resolution) derived from source hydrographic survey soundings collected by NOAA, NOAA's Ocean Service, Special Projects: Silver Spring, Maryland, accessed February 21, 2007, at http://estuarinebathymetry.noaa.gov/

National Ocean Service, 1998b, Estuarine bathymetric digital elevation models ( 3 arc resolution) derived from source hydrographic survey soundings collected by NOAA, NOAA's Ocean Service, Special Projects: Silver Spring, Maryland, accessed February 21, 2007, at http://estuarinebathymetry.noaa.gov/

New York City Department of Environmental Protection, 2004, 2004 New York Harbor water quality regional summary: New York City Department of Environmental Protection, accessed at http://www.nyc.gov/html/dep/pdf/ hwqs2004.pdf
New York Natural Heritage Program, 2002, NPS vegetation mapping program: Vegetation of Fire Island National Seashore: Albany, N.Y., National Park Service, accessed at http://biology.usgs.gov/npsveg/products/parkname.html

New York Natural Heritage Program, 2007, NPS vegetation mapping program: Vegetation of Gateway National Recreation Area: Albany, N.Y., New York State Department of Environmental Conservation.

Overton, W.S., Stevens, D.L., and White, D., 1993, Design report for EMAP: Environmental Monitoring and Assessment Program: Washington, D.C., U.S. Environmental Protection Agency, ORD, EPA/600/3-91/053.

Pendleton, E.A., Williams, S.J., and Thieler, E.R., 2004, Coastal vulnerability assessment of Fire Island National Seashore (FIIS) to sea-level rise: U.S. Geological Survey Open-File Report 2003-439, 15 p., accessed at http://pubs.usgs.gov/of/2003/of03-439

Pendleton, E.A., Thieler, E.R., and Williams, S.J., 2005, Coastal vulnerability assessment of Gateway National Recreation Area (GATE) to sea-level rise: U.S. Geological Survey Open-File Report 2004-1257, 27 p., accessed at http://pubs.usgs.gov/of/2004/1257

Reifsteck, D.M., Strobel, C.J., and Keith, D.J., 1993, Environmental Monitoring and Assessment Programnear coastal component: 1993 Virginian Province Field Operations and Safety Manual: Narragansett, R.I., U.S. Environmental Protection Agency, NHEERL-AED.

U.S. Army Corps of Engineers, 2004, Wave Information Studies: Kitty Hawk, N.C., U.S. Army Corps of Engineers, Field Research Facility, accessed at http://www.frf.usace. army.mil/frf.shtml

U.S. Environmental Protection Agency, 1993, EMAP laboratory methods manual: Estuaries: Cincinnati, Ohio, U.S. Environmental Protection Agency, Office of Research and Development, Environmental Monitoring Systems Laboratory, accessed at http://www.epa.gov/emap

U.S. Geological Survey, 2003, National land cover database zone 65 land cover layer 20030901: Sioux Falls, S.D., U.S. Geological Survey, accessed at http://www.mrlc.gov

U.S. Geological Survey, 2007, National Water Information System (NWISWeb): U.S. Geological Survey, accessed at http://waterdata.usgs.gov/nwis/si 

For additional information write to: New York Water Science Center

U.S. Geological Survey

2045 Route 112, BIdg. 4

Coram, NY 11727

Information requests:

(518) 285-5602

or visit our Web site at:

http://ny.water.usgs.gov 

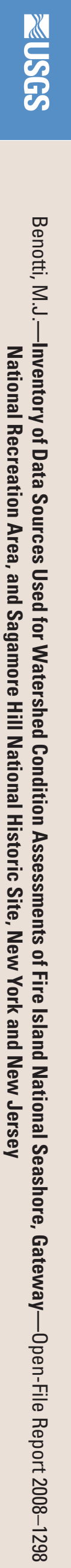